\title{
The Innovation of Public Governance based on Human Nature
}

\author{
Li Pengfei ${ }^{1}$ \\ School of Finance and Public \\ Management, Yunnan University of \\ Finance and Economics,Kunming, \\ Yunnan, China \\ lpf28@126.com
}

\author{
Dong Zhenzhen ${ }^{2}$ \\ School of Finance and Public \\ Management, Yunnan University of \\ Finance and Economics, \\ Kunming, Yunnan, China \\ 1145850810@qq.com
}

\author{
Yang $\mathrm{Jie}^{3}$ \\ School of Finance and Public \\ Management, Yunnan University of \\ Finance and Economics, \\ Kunming, Yunnan, China \\ 491049258@qq.com
}

\begin{abstract}
Self-interest is the most fundamental nature of human, which has been confirmed by gene science. The innovation of public governance in the world must be based on self-interest, because the interests of public relations are the transfer and intersection of private interests. The existing public governance system designed cannot fully and accurately
\end{abstract} reflect the nature and needs of human. The humanitarianism-oriented public governance as the moral orientation is based on human nature and relies on the new governance on the path of complete democratization, universal rule of law and equal exchange of interests.

Keywords-human nature; public governance; public and private relations

\section{INTRODUCTION}

The governance of government and non-governmental public organizations, in the final analysis, is the governance of and for people, namely people unites and governs their common life in a certain form of organization. The ultimate purpose of this governance is human happiness, but the premise for achieving this happiness is that human beings first have to maintain their own existence, otherwise they would eliminate themselves in the meaningless struggle against each other. Viewing from the aspects of international or group living, competition and cooperation exist forever. The double super-position of the two makes the public life full of vitality, order and safety. However, when competition increases, human public life will be threatened by disintegration risk; in turn, when cooperation increases that alliance is reached, human public life will be challenged by serious problems, because the countries or groups that constitute the alliance must damage the interests of countries out of the alliance. This is the deep embodiment of self-interest in human nature in the field of public administration. According to of view of gene science, the self-interest within human nature and its related animality have not changed for the past 90 thousand years, however, we still don't know if the culture developed on the basis of animality in human nature would be helpful for the rational human to overcome their own animality nature and directs the human public life to a new world.

\section{THE TRUE FEATURES OF THE}

\section{RELATIONSHIP BETWEEN PUBLIC AND PRIVATE}

It is generally believed that the value of public management is the interests of public relations, and public management is a human management activity for safeguarding and enhancing public interests. The true nature of public relations interests is private interest, for the gene is selfish and every individual is selfish. The existence for every individual is the primary issue. A man is a selfish person, not by purpose, but by the genes within, that the genes forces he (she) to be selfish, which as the ether said, "the living man is only a slave of the gene." People carrying the same or similar genes are instinctively inclined to safeguard 
the interests of the group, such as family members and clan members. Although everyone is selfish, human beings and animals, as a group, must learn to survive, Carle Marx said: "man is an animal that cannot be independent." As a result, the realistic individual needs to transfer his own private interests, which constitutes and forms the public interest, public finance, public facilities, public funds, public relations space, public relations order, public relations security and so on. The nature of public relations interests is private interests, the transfer and intersection of private interests.

However, once the private interests are transferred, the ownership seems to be no longer be personal, and the right of the ownership is also occupied by the government and non-governmental public organizations, namely, individuals and organizations with public power have become the owners of public relations interests. As the government and non-governmental public organizations are also made up of selfish individuals, the government and non-governmental public organizations have the dual nature of class and public nature without exception. Class nature is determined by the self-interest of individual genes, and the public nature is determined by the social survival of human beings. It is the interdependent characteristics of genes. In the final analysis, we must obey the operation rules of the gene society, and every individual and even the human race is helpless for the fact.

\section{THE PRACTICAL SYSTEM OF PUBLIC MANAGEMENT}

\section{BASED ON SELF-INTEREST}

Based on recognizing individual self-interest, human beings have designed the free market economy system and the political system with check and balance. According to the specific geographical position and historical tradition, the group and the nation, relying on "hard strength" and "soft power", constructed their own country and maintain the same or similar genes, as well as different genes that infiltrate into sometimes. The constructed country needs to rule and govern the classes and public. Today, the public management is the main duty of the government, which becomes the pronoun of the government for solving public problems, meeting public needs, resolving public contradictions and providing public service.
The worldwide practice of public management reveals that the days that government providing exclusive public services to public needs cannot be retrieved. Public and private cooperation, PPP model, joint governance, and contract governance have become fashionable nouns in field of public management. It is an inevitable requirement to improve the performance of public services ostensibly, in fact, it is the point where human nature steps from competition to cooperation, from jealousy to sympathy and from hatred to tolerance. The design of the public management system in the world today is based on the self-interest of the humanity, on the basis of rational consideration of the relationship between the government and the market, the government and the enterprise, the government and the society. The common practice is to realize the cooperation between the government and non-governmental public organizations, the enterprises and the society in the country. The cooperation between countries and countries is a proper solution to the public problems for a country and the international community so as to achieve sustainable development of public governance. However, can cooperation transcend human selfishness, cultural differences and even national interests? Cooperation can really be achieved. How can we achieve shared risk and benefit sharing? What is the basis of the human philosophy of cooperation?

\section{THE TRANSFORMATION}

\section{OF HUMANITARIANISM-ORIENTED PUBLIC GOVERNANCE}

Since the self-interest has not been changed for the last 90 thousand years, the public governance that transcends self-interest is virtually impossible, unless at some point in the future another genetic mutation occurs to human beings like the ancestor of the Homo sapiens. Based on the self-interest of genes, it is very important to reconsider the philosophical foundation of the worldwide public governance innovation. The philosophical foundation that transcends human selfishness is humanitarianism. The core essence of humanitarianism is "treat everyone well" and "make man as a man".

The reason why we should treat all people well is that the person in real life shares common ancestor and common genes. According to the research results of the human genome, 
there are only $0.1 \%$ genetic differences between different people living in the real world. Although different species, they all have the common ancestor, the Homo sapiens. In this way, transcendental philosophy and empirical science provide a theoretical basis for public governance and make humanitarianism an important value basis for the public governance in the new era.

We want to make man as a man because the highest and ultimate value pursuit for a man is self-realization. If everyone can become the person they want to and achieve self-realization, it is not only the success of the design of the public governance system, but the victory of the theory of human nature, the achievement of getting rid of the state of slavery, alienation and achieving liberty.

Therefore, for the largest public organization-the government and non-governmental public organizations, the most perfect moral principle is to treat everyone well and treat everyone as human beings. Only by adhering to these two principles can we build a solid foundation for the legitimacy of public organizations and successfully accomplish our historical mission. Of course, in such a historical process, the disappearance of the government is inevitable. The governance of the future society is a netted public governance without the government and everyone is the master.

\section{THE PATH DEPENDENCE OF PUBLIC}

\section{GOVERNANCE INNOVATION}

Realistic

public governance innovation

has some specific constraints: first, the establishment of a completely equal democratization system. The democratization of all countries in the world today is either democratization under the control of capital, or democratization under the control of power, or democratization under the control of religion, or democratization under the control of the patriarchal clan, and democratization based on the equality of everyone's personality is rare, that is, unconditional and absolute democracy, and the realization of the foundation. There is no way out for humanitarianism and future oriented democratization. Second, the norms of international law are universally adopted. For today's international law system, not every country identifies, joins or approves, many countries have a choice of identity from their own private interests, some disregard international law, some override the international law, which shows that the system of national law has not become a universal norm of state behavior, not to be observed; third, the principle of "sharing risks and sharing interests" has become the fundamental law of public-private partnerships. The basis of public and private cooperation is equality, which does not allow the public sector, especially the government to override the private sector, to damage the interests of the private sector, and to let the private sector override the public sector and let the public sector be humiliated.

\section{CONCLUSION}

To realize the innovation of public governance, we must take human nature as the basis of system and policy design, the system and policy of human nature for a long time, and the system or policy of distorting or violating human nature will eventually be eliminated and waste lots of resources. It is believed that in all aspects of efforts, public governance innovation worldwide can become a reality, and a new unprecedented pattern of governance will eventually take shape.

\section{REFERENCE}

11] [Canada] Charles, Ramsden, et al. Gene, mind and culture: coevolution process $[\mathrm{M}]$, Liu Li translation, Shanghai: Shanghai science and Technology Education Press, 2016.

[2] [America] David Farmer. The language of Public Administration: bureaucracy, modernity and post modernity [M], Wu Qiongyi, Beijing: Renmin University of China press, 2017

[3] [America] George Fredrickson, [M], the spirit of public administration, Zhang Chengfu. Translation: Beijing: Renmin University of China press, 2003.

[4] [America] Charles Fox, Fawkes. Postmodern public administration discourse directed at $[\mathrm{M}]$, Chu Yanhong et al. Beijing: Renmin University of China press, 2002

[5] [America] Peter J. Richerson, et al. Beyond gene: how culture changes human evolution [M], Chen Shu et al. Hangzhou: Zhejiang University press, 2017.

[6] Kong Xianduo et al. Gene and human nature [M]. Beijing: Peking University press, 2009. 